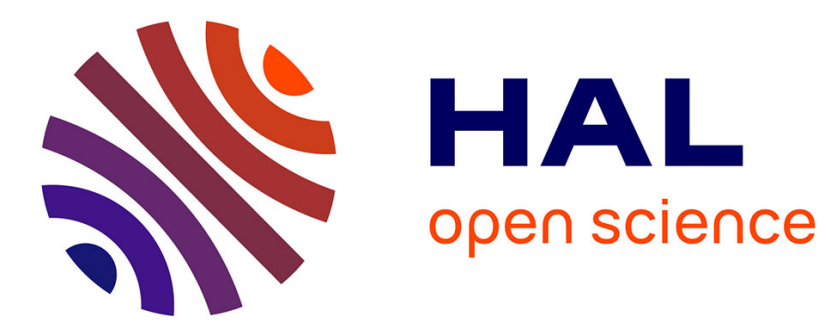

\title{
The News Coverage of the 2004 European Parliamentary Election Campaign in 25 Countries
}

Claes H. de Vreese, Susan A. Banducci, Holli A. Semetko, Hajo G. Boomgaarden

\section{- To cite this version:}

Claes H. de Vreese, Susan A. Banducci, Holli A. Semetko, Hajo G. Boomgaarden. The News Coverage of the 2004 European Parliamentary Election Campaign in 25 Countries. European Union Politics, 2006, 7 (4), pp.477-504. 10.1177/1465116506069440 . hal-00571734

\section{HAL Id: hal-00571734 https://hal.science/hal-00571734}

Submitted on 1 Mar 2011

HAL is a multi-disciplinary open access archive for the deposit and dissemination of scientific research documents, whether they are published or not. The documents may come from teaching and research institutions in France or abroad, or from public or private research centers.
L'archive ouverte pluridisciplinaire HAL, est destinée au dépôt et à la diffusion de documents scientifiques de niveau recherche, publiés ou non, émanant des établissements d'enseignement et de recherche français ou étrangers, des laboratoires publics ou privés. 


\section{EUP}

European Union Politics

DOI: $10.1177 / 1465116506069440$

Volume 7 (4): 477-504

Copyright@ 2006

SAGE Publications

London, Thousand Oaks CA,

New Delhi
The News Coverage of the 2004 European Parliamentary Election Campaign in 25

\section{Countries}

\section{Claes H. de Vreese}

University of Amsterdam, The Netherlands

\section{Susan A. Banducci}

University of Exeter, UK

Holli A. Semetko

Emory University, USA

Hajo G. Boomgaarden

University of Amsterdam, The Netherlands

\section{ABSTRACT}

This article analyses the news coverage of the 2004 European parliamentary elections in all 25 member states of the European Union (EU). It provides a unique pan-European overview of the campaign coverage based on an analysis of three national newspapers and two television newscasts in the two weeks leading up to the elections. On average, the elections were more visible in the 10 new member states than in the 15 old EU member states. The political personalities and institutional actors featured in news stories about the elections were generally national political actors and not EU actors. When evaluative, the news in the old EU-15 was generally negative towards the EU, whereas in the new countries a mixed pattern was found. The findings of the study are discussed in the light of the literature on the EU's legitimacy and communication deficit. 


\section{Introduction}

The 2004 European parliamentary (EP) elections were an unprecedented exercise in democracy, with more than 350 million people in 25 countries having the opportunity to vote. The elections took place only weeks after the accession of 10 new member states to the European Union - the largest enlargement ever. Most voters in both the old EU-15 and the 10 new member states experience politics primarily through the media. Particularly in the case of low-salience, second-order elections, most of what citizens know about the campaign stems from the media (Bennett and Entman, 2001; see also Eurobarometer 162). Empirical knowledge about the media's coverage of EP elections is a prerequisite for assessing the well-being of democratic processes in Europe and for informing the ongoing discussion about the EU's democratic and communication deficits.

Observations of the democratic process in the EU have been dominated by the 'democratic deficit'. This deficit has been identified as one of the major shortcomings of European integration and has been conceptualized in terms of institutional design and linkage institutions that focus on national rather than EU issues (Coultrap, 1999: 108; Kuper, 1998; Scharpf, 1999). The unelected nature of the Commission, the lack of European parliamentary power in policy-making, and the dominance of national issues are reflected in a lack of popular support, legitimacy and engagement in the EU among EU citizens (e.g. Eichenberg and Dalton, 1993).

The importance of the media in alleviating or contributing to the democratic deficit lies in the media's ability to contribute towards a shared framework of reference and a European identity. First, the lack of EU legitimacy is viewed as a communication deficit (Meyer, 1999; Anderson and McLeod, 2004). According to this view, EU institutions have been unsuccessful in shaping European identity and promoting the connection between citizens and EU institutions via the media (Anderson and Weymouth, 1999; Anderson, 2004). Although the EU, and the European Parliament specifically, need to promote themselves, they are oftentimes confronted with media outlets that are either sceptical or uninterested (Anderson and McLeod, 2004; De Vreese, 2002; Meyer, 1999). Accordingly, negative news and, in general, a lack of news regarding the EU and $\mathrm{EP}$ are thought to contribute to a lack of legitimacy and to detract from the formation of a European identity.

Secondly, the lack of a European public sphere has been referred to as the public communication deficit (Scharpf, 1999; Schlesinger, 1999). From this perspective, the development of European democracy depends on the existence of a European public sphere, which entails a common public debate carried out through a common European news agenda (Schlesinger, 1995), 
ideally in a European media system (Grimm, 1995, 2004). Several scholars have formulated minimal criteria for a European public sphere. The criteria include corresponding media coverage in different countries with shared points of reference in which 'speakers and listeners recognize each other as legitimate participants in a common discourse that frames the particular issues as common European problems' (Risse and Van de Steeg, 2003: 21). At the very least, a European public sphere should reflect national media reporting on the same topic using common sources, including EU sources and sources from other EU countries. Therefore, a discussion of European issues amongst a set of EU actors in the media is important to the development of a European public sphere, or Europeanized national spheres, that will sustain democracy in the European Union and develop it further.

In the research on media and the EU democratic and communication deficits, links have been established between media coverage of the EU and public perceptions of EU legitimacy, mass support and citizen engagement in elections. In particular, three aspects of EU media coverage tend to influence public perceptions, similar to those that have been identified as important in the EU public sphere. These three aspects of media coverage are EU visibility (or quantity of coverage), the European nature of the coverage and its tone. Greater visibility of European campaigns is related to higher turnout in European parliamentary elections (Banducci and Semetko, 2003, 2004). Greater visibility of EU news is related to knowledge gains about the EU (De Vreese and Boomgaarden, 2007), and a greater visibility of pro-EU actors tends to influence support for EU membership positively (Banducci et al., 2002). Finally, negative news about the EU has been found to be related to negative public evaluations of the EU (Norris, 2000a).

Our intent in this study is not to report on how the media shape public perceptions, but to provide a detailed examination of media content across the $25 \mathrm{EU}$ member states in order to better assess the possible role the media can play in enhancing EU democracy. Structured knowledge about the media's coverage of European elections is only emerging and we have virtually no knowledge about the way in which news media in the new member states approach European political and economic topics. Studies of the European public sphere tend to focus on quality newspapers or magazines and tend to cover only a handful of countries (for example, Van de Steeg, 2002; Meyer, 2005; Peters et al., 2005; and Trenz, 2004), or not all member states (Kevin, 2003). Our study contributes to the debate on the democratic deficit, the media and EU public opinion by providing analysis of media content across print and television in all the current member states. In this article, we report the findings of an unprecedented EU-wide study of the news media's coverage of the 2004 EP elections. We provide contextual information 
to understand the campaign as reported by television and newspapers in each country and assess the developments in the media's coverage by comparing it with the previous 1999 EP election campaign in 15 EU countries.

Interest in the extent to which news media coverage contributes to the democratic deficit or to a European public sphere leads to three key foci of the study. First, we analyse the general news environment in Europe during the campaign for the 2004 EP elections and we assess the visibility and amount of attention devoted to the elections by national news media. Contributing to a European public sphere, increased visibility of the elections in the news gives voters an indication of the salience or importance of the election. In addition, visible news coverage is expected to give voters information about candidates and party positions. Second, addressing both the public sphere and the democratic deficit, we investigate the extent to which national news media presented the elections as a national or a European event. European parliamentary elections have been characterized as secondorder national elections (Reif and Schmitt, 1980). This implies two particular characteristics about the European parliamentary election campaigns: low campaign intensity and national, not European, issues on the agenda. The content analysis of the news coverage allows us to assess the extent to which coverage of the campaign focuses on EU-level versus national-level actors. Greater emphasis on EU actors indicates a European public sphere whereas a greater emphasis on national actors contributes to the democratic deficit. Third, we assess the tone of the news coverage towards the EU. The invisibility of the EP in the news and the negative tone in coverage of the EU have been cited as contributing factors to the democratic deficit in terms of negative attitudes about the EU (Norris, 2000b) and low participation in EP elections (Norris, 2000a).

All of these aspects are addressed in a comparative fashion. In addition to cross-national comparisons, we distinguish between media, groups of countries and elections. We compare the coverage of television and newspapers, public and commercial networks, and broadsheets and tabloids. We furthermore contrast the coverage in the old EU-15 countries with the coverage in the new 10 countries. Finally we look at differences over time by investigating changes in the coverage compared with the 1999 EP elections. We develop the importance of these comparisons below.

As a secondary focus, the data reported will be a useful resource for researchers examining public opinion, elections and media influences in the context of the European Union. The study reports characteristics of coverage across all member states in 1999 and 2004 using standardized measures across countries and years. The results reported here thus provide values on important contextual indicators. Although the results and the analysis are largely 
descriptive, other researchers can incorporate these measures into their own research on the European Union.

\section{News and information in European parliamentary elections}

This study of the news coverage of the 2004 EP elections takes place in the context of a highly competitive news and information environment in Europe. Whereas in the 1980s television broadcasting in Europe consisted mainly of publicly funded monopolies, by 2004 virtually all countries in the EU had a dual system of broadcasting, with public and commercial stations coexisting and competing (Brants and de Bens, 2000). During the past 20 years the newspaper market in Europe also changed, and by 2004 newspaper readership was in decline, though still considerable in many European countries (Lauf, 2001). The structural developments in the news market are important because of the choice citizens have for finding political news in the available outlets. Commercial television usually provides less 'hard' political news (Blumler, 1997; Pfetsch, 1996) and less news about issues of European integration (Peter and de Vreese, 2004). ${ }^{1}$

\section{How visible is the EU on the news agenda?}

Coverage of European affairs tends to be cyclical in nature, with coverage of the EU virtually absent from the news agenda and then peaking around important EU events, to vanish off the agenda again (De Vreese et al., 2001; Norris, 2000a). This pattern of news coverage has been found to apply to EU summits, which are pivotal moments for EU decision-making and where news coverage of EU affairs is much more visible than during 'routine periods' (De Vreese and Boomgaarden, 2006; Peter and de Vreese, 2004; Semetko and Valkenburg, 2000). During other key events, such as national referendums on issues of European integration, EU news can take up a substantial part of the news agenda, especially in the final weeks of the campaign (De Vreese and Semetko, 2004). During routine periods, i.e. outside the referendum periods and when there are no scheduled events of the magnitude of European Council meetings for example, EU politics is marginal in national news (Gerhards, 2000; Peter and de Vreese, 2004; Peter et al., 2003).

Although some studies have focused on the Europeanization of the media in a single country (e.g. Koopmans and Pfetsch, 2003) or the coverage of particular cases by media across countries (e.g. De Vreese et al., 2001; Meyer, 2005; Risse and Van de Steeg, 2003; Trenz and Münzing, 2003), our knowledge about the way in which EP elections specifically are covered is quite limited. 
The 1979 campaign was virtually absent from the media agenda until the final weeks before the elections (Blumler, 1983; Siune, 1983). No systematic and comprehensive cross-national study of media coverage was carried out until the 1999 EP elections. In 1999, a research team at the Amsterdam School of Communications Research conducted an analysis of the most widely watched television news programmes in the then 15 EU member states in the two weeks leading up to the 1999 European elections. The results showed that the average portion of the programme (based on time) about the election in the main evening news programmes for all EU member states was about $7 \%$. Belgium, Germany, Ireland, the Netherlands, Spain and the United Kingdom devoted less than 5\% of news to the elections. Austria, Denmark, Finland, France, Greece, Italy and Sweden are somewhat above average, spending 8-13\% of news time on European elections (De Vreese et al., 2006; Peter et al., 2004).

The visibility of the EP elections matters. Information about key democratic moments such as elections in the news is a prerequisite for enhancing public awareness and possible engagement in EU politics. Moreover, the EU, faced with challenges of legitimacy and unclear structures for political accountability, is dependent upon media coverage to reach its citizens.

\section{Representative democracy? The absence of EU representatives}

In addition to the visibility of the elections in the news, the presence of political personalities and actors at the EU level (such as candidates for the EP and members of EU institutions) is a necessary condition for the functioning of political representation in a democracy (De Vreese, 2002). The visibility and identification of potential representatives is a prerequisite for a healthy democratic process. One of the features of the democratic deficit is that European parliamentary elections are contested by national parties that clash over national or domestic cleavages and not over European issues. The secondorder theory of EP elections (Reif and Schmitt, 1980) posits that EP elections take a secondary role to national politics and are largely contested over national not EU issues. Looking at actors in the news can therefore give us an assessment of whether the news covers European elections as either a national or a European contest.

Several studies have investigated the visibility of actors in national election campaigns (e.g. Semetko and Schönbach, 1994; Semetko et al., 1991; Van Praag and Brants, 2000). However, we have only scant knowledge about the representation of the EU in the news. Analyses of the 1999 EP elections suggest that EU actors were much less visible than national actors (De Vreese et al., 2006), especially in countries that were long-standing members of the 
EU (Peter et al., 2004). With regard to this pattern and in the light of the 2004 enlargement, it is relevant to assess whether EU actors were evident in the news in Europe.

\section{How negative is the news about the EU?}

News is largely neutral and the number of explicit evaluations is generally limited but, when evaluations are present, they tend to be negative. This pattern is inherent to the news genre and has been demonstrated also to apply to political news (Kepplinger and Weissbecker, 1991). In the case of the EU, this pattern does not appear to be much different. Norris (2000a), in her reanalysis of the EU Commission's media monitor reports, found that news about several EU policies as well as about EU institutions tended to be tilted towards negative evaluations. In an analysis of the media coverage of the 1999 EP elections, Banducci and Semetko (2004) found that negative news about the EU matters for democratic participation but not necessarily in the way one would expect. More negative news about the EU tended to mobilize the electorate up to certain point. However, when the volume of negative news became greater, an individual's probability of voting declined. Thus, evaluative media content is an important parameter for assessing the nature of public debates, because evaluative media content provides important cues for citizens' perception of the EU.

\section{Comparing news media coverage across outlets, elections and countries}

Visibility, European focus and tone constitute the main dependent variables in the study. Based on an understanding of national media systems, reporting differences between different news outlets, the salience of European elections and the importance of the European parliament, we do expect variation in these dependent variables across outlets and countries. First, we make comparisons that relate to expected differences produced by the outlet. The type of media (print vs. television), the financing structure of the broadcasting outlet (public vs. commercial) and the nature of the newspaper (tabloid vs. broadsheet) have been shown to produce differences in the quality and style of news reporting. Newspapers generally have more political news than does television news, because they have far fewer constraints in terms of space and production costs. Public broadcasters tend to have more political and economic news (Pfetsch, 1996) and in particular more news about European integration than do commercial broadcasters (see Peter and de Vreese, 2004). 
We also expect political considerations to produce variation in media coverage across countries and across election years. There has been an increase in the powers of the European Parliament since the 1999 election (Kreppel, 2002; Hix et al., 2003). As the policy-making power of the institution increases, the salience of elections for members of the European Parliament should increase. The view of EP elections as second-order affairs is based on the perception that these elections are not salient because nothing is at stake (Reif and Schmitt, 1980). However, with the increased importance of the European Parliament, stakes were higher in the 2004 election. The differences in the amount of attention paid to the elections by the news media should reflect this increased importance.

The addition of 10 new member states in May 2004 may have also increased the salience of the elections. Given the novelty of the event (Peter et al., 2004), we expect the visibility of the EP elections to be higher in the new member states than in the old EU-15. Finally, given the second-order perspective on media coverage of European elections (De Vreese et al., 2006), we expect non-EU actors to dominate the news about the elections in general. However, given greater experience with EU politics and greater familiarity with EU actors, EU actors may be more prominent in the older member states and there may be a greater focus on domestic actors in the new member states.

In summary, given the extant knowledge about national media systems, styles of news coverage and the status of the European Parliament discussed above, we have the following expectations regarding coverage of the EP campaigns.

First, given the growing importance of the European Parliament in EU decision-making and the recent enlargement, we expect the visibility in the news of the EP elections to be higher in 2004 than in 1999. We expect the visibility of the 2004 EP elections to be higher in the new countries than in the old member states given the novelty of the event, and we also expect the visibility of the EP elections to be higher on public broadcasting news and in broadsheet newspapers than on commercial television news and in tabloid papers.

Second, characterization of EP elections as second-order national elections leads us to expect that news about the EP elections is dominated by domestic political actors. However, quality newspapers and public broadcasters will give more prominence to EU actors when compared with other outlets, with quality newspapers giving the greatest prominence.

Third, news about the EP elections is mostly neutral and, if evaluative, negative in tone. Based on previous research (De Vreese et al., 2006), we expect news, when evaluative, to be negative towards the EU. We have no a priori 
expectations about differences in the tone of the news across years, new and old member states or the type of outlets.

\section{Content analysis of news media coverage during the EP campaign period: Research design and method}

To study the news coverage of the 2004 EP elections, a media content analysis was carried out in all 25 member states of the EU. ${ }^{2}$ We include two television news programmes and three national newspapers from each country. We focus on national television and newspapers because these media are consistently listed as the most important sources of information about the EU for citizens in Europe (Eurobarometer 54-62) and because television and newspapers were the two most widely cited sources in which citizens were exposed to information about the 2004 elections (Eurobarometer 162). In each country we include the main national evening news broadcasts of the most widely watched public and commercial television stations. We also include two 'quality' (i.e. broadsheet) and one tabloid newspaper from each country. These media outlets were selected to provide a comprehensive idea about the news coverage in each country. For reasons of comparability between media and with the 1999 elections, we focus on the final two weeks of coverage.

Our television sample consists of 49 networks and the newspaper sample consists of 74 different newspapers. ${ }^{3}$ An overview of missing days (owing to technical problems) is provided in the appendix to this article. For television, we coded the entire news programme of each station. Given that the length of news programmes in Europe varies (from 15 to 60 minutes) and given that the number of news stories per programme differs too, we base all analyses on the length of the individual news story in relation to the total length of each news programme. Our unit of coding and analysis is the individual news story, defined as a change of topic, typically introduced by the anchor person. In total, 9339 television news stories were analysed. For newspapers, we also used the individual news story as the unit of analysis. We coded all stories on the front page of the newspaper as well as a random page inside the main section of the newspaper and all news stories about the EP elections throughout the newspaper. In the analyses presented here, we use the analysis of the front pages as the base, for reasons of comparability with the study from 1999. The sample size for this analysis is 8280 .

\section{Coding procedure}

Under supervision and in close cooperation with the principal investigators, coding was conducted by trained and supervised coders. Coder trainers were 
trained with the codebook for the study developed by the principal investigators. Individual coders were recruited based on their language capabilities. They completed initial training and only when their coding was of sufficient quality (assessed by coder tests that were matched with master codes completed by the coder trainer team), actual coding commenced. Given the challenges in cross-national content analysis (see Peter and Lauf, 2002), coders were monitored and intra- and intercoder-reliability tests were conducted. The results of these tests were satisfactory (between 80 and 100\% agreement).

\section{Measures}

Our first measure used here is visibility of the EP elections. Each news story was coded for topic. News about European elections was designated a range of codes that enabled us to identify when a story was about the elections and what the specific topics of these stories were. To tap the domestic versus European nature of the story, we relied on the coding of actors in the news. An actor is defined as a person (e.g. MEP candidate), groups of persons (e.g. political party), institution (e.g. national parliament) or other organization (e.g. Red Cross) featured in the story. Up to 20 actors per news story were coded. Coders first identified the main actor (in terms of importance) and then other actors in order of appearance. Actors were classified as EU actors, domestic political actors or other actors. EU actors comprise EP candidates as well as the EU President and EU Commission members. Domestic political actors are members of the government, spokespersons for government agencies or members of opposition parties. This includes all members of the national parliaments. The category of other actors includes journalists, celebrities, ordinary citizens and other actors that do not fall into the EU or domestic political actor categories. ${ }^{4}$ For each election story, a maximum of 20 actors could be coded, and across all news stories a total of 19,851 actors were coded. Coders also noted whether the tone of coverage towards the actor was neutral, negative or positive. For tone of the news we relied on explicit evaluations of the European Union, its institutions and/or policies. News was coded for being either neutral (i.e. no evaluation present), negative or positive, predominantly negative or positive, or mixed.

\section{Data analysis}

In our analyses of the general news environment, the visibility of the elections as well as the tone of the news, we use the individual news story as the unit of analysis. In the analysis of the presence of different actors in the news, the individual actors are the unit of analysis. 


\section{Results}

\section{More news about the elections}

We first turn to the visibility of the 2004 EP elections in national news media. Looking at television news, we found that EU news took up $9.8 \%$ of the news, on average, in the two weeks leading up to election day. The average visibility of EU news in 2004 was higher in the new member states (10.4\%) than in the old member states $(9.2 \%)$. Of the news about the EU, $80 \%$ on average was devoted specifically to the EP elections.

Figure 1 displays the visibility of news about the EP election and of other EU-related issues in television newscasts during the 1999 and 2004 EP election campaigns. ${ }^{5}$ The 15 old EU countries are displayed on the left-hand side and the new member states, which took part in the EP elections for the first time in 2004, are shown on the right-hand side. The EU-wide average of $9.8 \%$ contains significant cross-national variation. In Greece, for example, the elections took up $21 \%$ of the news, whereas in Germany the elections took up

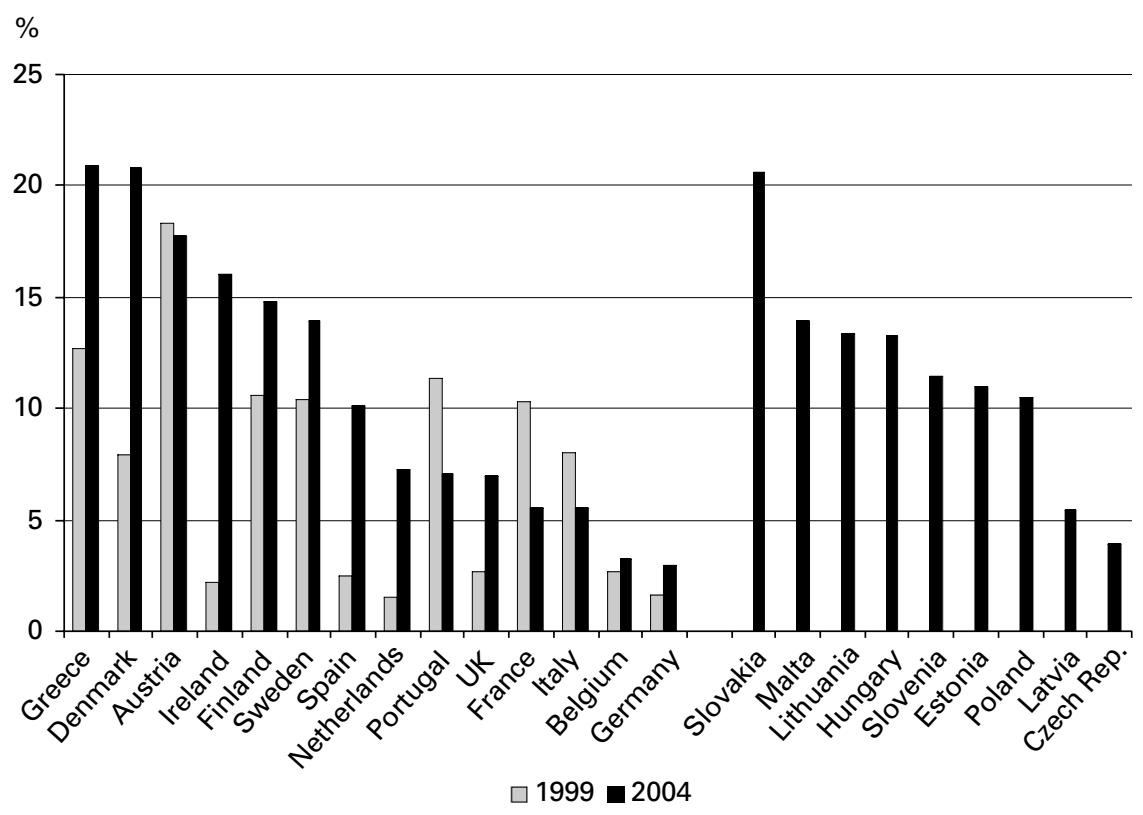

Figure 1 Visibility of EU news in television newscasts, 1999 and 2004.

Notes: Values are length-based percentages within the countries and election periods. All stories in television newscasts were included. Values display the proportion of news stories about the EP election and about other EU news. 1999: $n=4781 ; 2004: n=9339$. 
only $3 \%$ of the news. In addition to Greece, the elections were most visible in Denmark, Slovakia, Austria, and Ireland, taking up more than $15 \%$ of the news in these countries. In addition to Germany, the elections were least visible in Belgium and the Czech Republic, where less than $5 \%$ of the news was devoted to the elections.

On average, in the old member states we found an increase in the news devoted to the EP elections from $6.6 \%$ in 1999 to $9.2 \%$ in 2004 , and 10 of the 15 old member states showed an increase in visibility. Among the new member states, seven countries showed more than $10 \%$ EU news.

Turning to national newspapers, Figure 2 shows the visibility of EU news on newspaper front pages, again with the results for the new member states displayed on the right-hand side and the comparison between 1999 and 2004 for the old member states on the left-hand side. The picture shown here is slightly more differentiated than for television. Overall, in all 25 member states $5.9 \%$ of front-page stories were devoted to EU news. EU news was most visible in Malta, Cyprus, Greece and Austria. The smallest proportion (less than $4 \%$ ) of EU news on newspaper front pages was found in the Netherlands, Belgium and Lithuania.

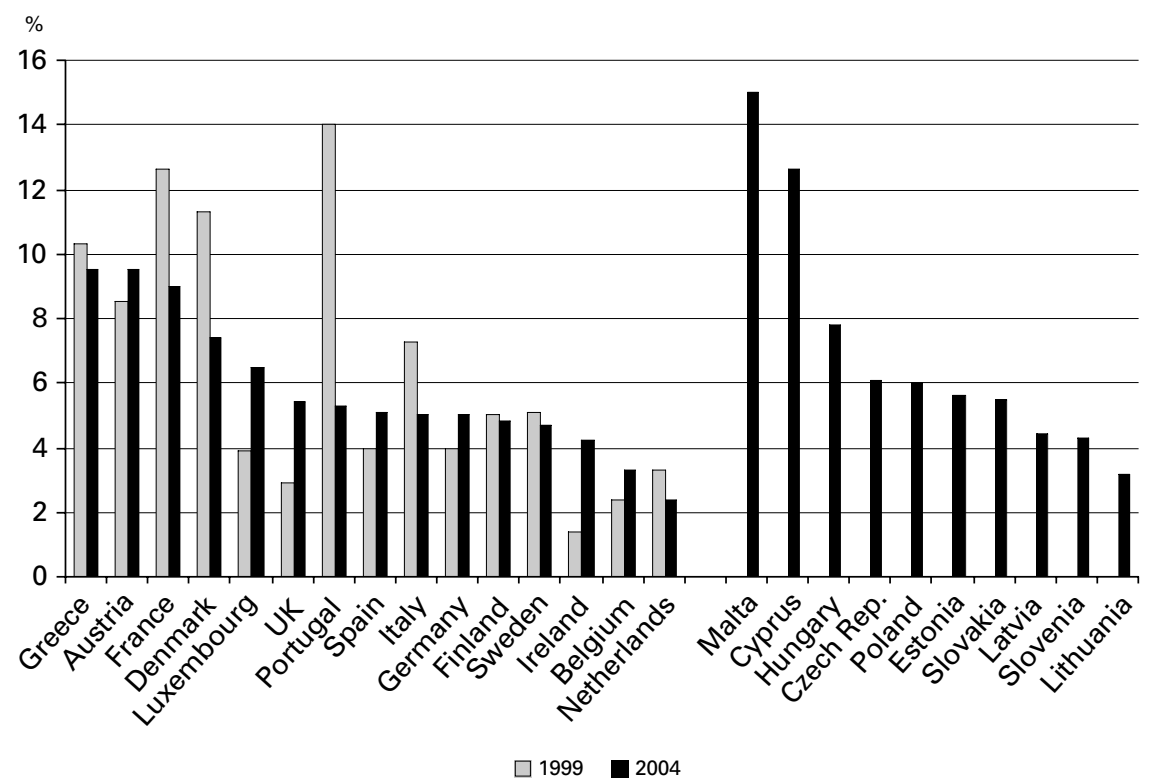

Figure 2 Visibility of EU news on newspaper front pages, 1999 and 2004.

Notes: Values are story-based percentages within the countries and election periods. All stories on newspaper front pages were included. Values display the proportion of news stories about the EP election and about other EU news. 1999: $n=2224 ; 2004: n=8280$. 
Whereas in 1999 there were $6.2 \%$ of front-page stories about EU news in the 15 old member states, in 2004 this slightly decreased to $5.6 \%$. The four countries with the highest amount of news in 1999 (Portugal, France, Denmark and Greece) all showed a decrease in visibility. The three countries with the lowest visibilities in 1999 displayed an increase in 2004. Portugal showed the sharpest decrease in front-page stories devoted to EU news, from $14.0 \%$ to $5.3 \%$, and the UK the highest increase, from $2.9 \%$ to $5.4 \%$.

Comparing the visibility in 2004 in the old versus the new member states, we see again a higher overall visibility on newspaper front pages in the 10 new member states. Whereas in the old member states the overall proportion of EU news stories was 5.6\%, it amounted to $6.1 \%$ in the new member states. However, the pattern is less clear compared with television news. Of the 10 new countries, the two states with the highest visibility in newspapers are the two smallest member states - Malta and Cyprus.

Looking at the visibility of EU news in 2004 in public broadcasting and commercial television news as well as in broadsheet versus tabloid newspapers, we find support for our second expectation. Figure 3 shows that the EP elections were consistently more visible on public broadcasting news programmes than on commercial television news. The elections were also covered more extensively on the front pages of the broadsheet press than in the tabloid press. Moreover, Figure 3 shows that, in commercial television news and in the broadsheet press, the new member states gave more room to the elections than did the outlets in the old member states.

Looking specifically at television news about the elections (which was $79.5 \%$ of all EU news in 2004 and $84.8 \%$ in 1999) and comparing the visibility in public broadcasting news and commercial television news in 1999 and 2004, we find that public broadcasters devoted more time to the elections than their commercial counterparts did (see Figure 4). This pattern was found in 1999 (with $6.3 \%$ of public news and $4.9 \%$ of commercial news devoted to the elections) and again in 2004 (with $9.5 \%$ of public news and $5.2 \%$ of commercial news devoted to the elections). Whereas the share of EP news in commercial news remained largely the same in 1999 and 2004, public broadcasters increased the visibility of the elections.

In conclusion, the media attention rose for the 2004 EP elections compared with the 1999 elections. This increase in visibility was driven primarily by the new member states, which devoted a higher share of the news (both on television and in newspapers) to the elections than the old countries did. The overall increase on average was in particular driven by newspapers in Malta and Cyprus and by public broadcasting television news.

As a final note with respect to the visibility of the elections, we briefly discuss the general news and information environment in the EU during the 


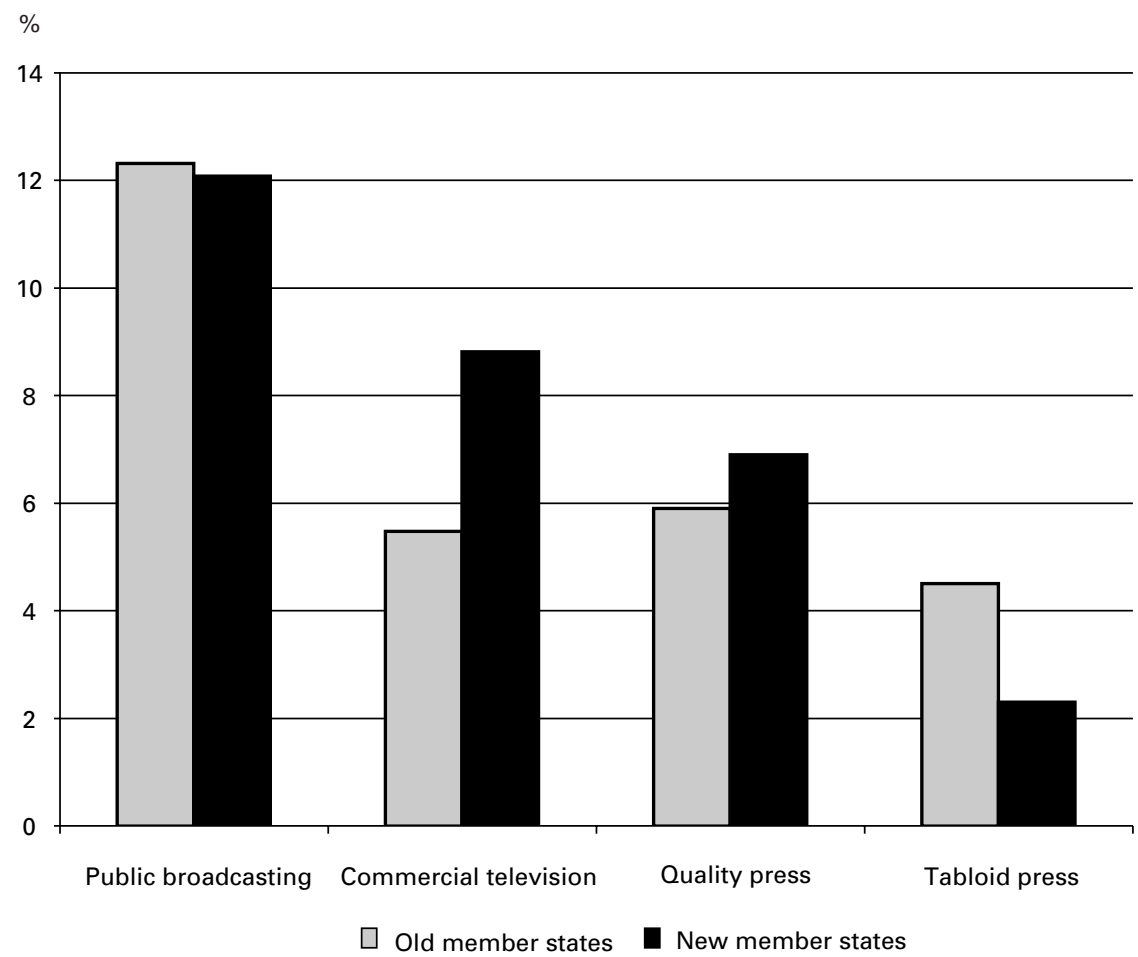

Figure 3 Visibility of EU news in television newscasts and on newspaper front pages in 2004.

Notes: Values are length-based percentages within the categories and election periods. All stories in television newscasts and on newspaper front pages were included. Values display the proportion of news stories about the EP election and about other EU news. Television newscasts: $n=9339 ;$ newspaper front pages: $n=8280$.

campaign. In terms of the time spent on issues in the news, the EP elections in 2004 came further down the list than news about domestic and social policies, sport and economy/business, but ahead of domestic party politics and crime. Compared with 1999, the news agenda in 2004 was less dominated by international conflicts, which were very high on the news agenda in 1999 with the Kosovo conflict. In 2004, the Iraq conflict did not attract a similar level of attention. ${ }^{6}$

\section{European elections: Slowly expanding the domestic battlegrounds}

Figure 5 shows the proportion of actors featured in stories about the EP election across the $25 \mathrm{EU}$ member states. A comparison is also made with the 


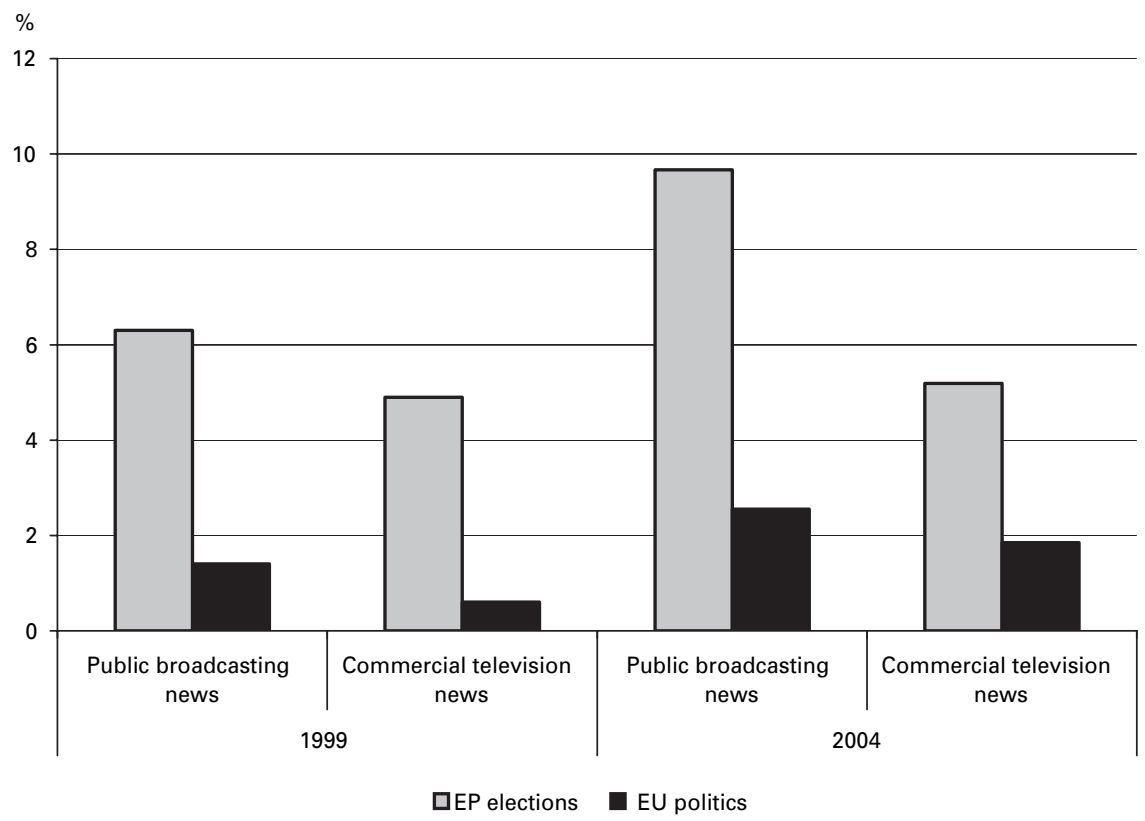

Figure 4 Visibility of EP election and other EU news, 1999 and 2004.

Notes: Values are length-based percentages within the categories and election periods. All stories in television newscasts were included. Values display the proportion of news stories about the EP election and about other EU news. 1999: $n=4781 ; 2004: n=9339$.

actors featured in the coverage of the 1999 EP election. Clearly, in both election years, domestic political actors dominated the coverage of the EP elections. In 1999, four countries (Germany, Ireland, Portugal and Sweden) either had no EU actors in EP election stories or they did not exceed 1\%. The Netherlands was the only country where EU actors were more frequently featured than domestic actors in EP election news, but in 1999 there were only two stories on national television news about the elections. This indicates that the second-order nature of EP elections was reflected in the news coverage, possibly detracting from the European public sphere.

When examining the main political actors, some changes are evident in 2004. Although the coverage was still focused on domestic actors, there was an overall increase in the proportion of EU actors. In several countries, the proportion of EU actors reached or exceeded the proportion of domestic political actors (Malta, Portugal and France). Similar patterns are evident when looking at the other actors in the news stories. Across the member states, countries that had a higher proportion of main protagonists that were EU actors also had a high proportion of other actors that were from the EU. 


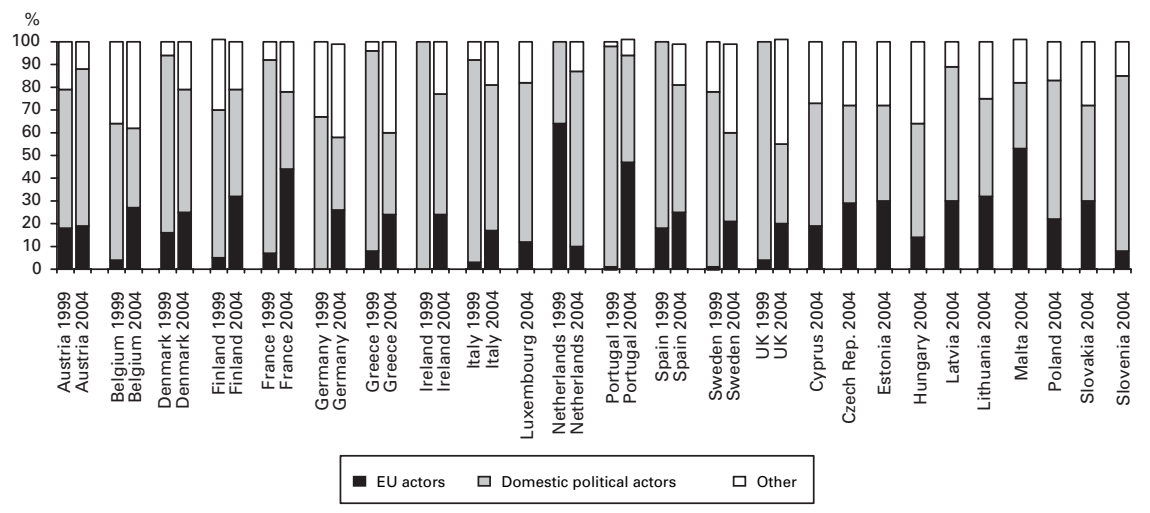

Figure 5 Actors in the news: EU actors, domestic actors and other actors.

Note: The figure compares all actors in the news in 1999 with the main protagonists in 2004.

Therefore, although EP election news coverage still predominantly featured domestic political actors, there was an increase from 1999 in attention paid to EU actors. In all member states during the 1999 election, 83\% of actors in EU election stories were national political actors, whereas in 2004 a comparatively lower proportion (50\% for main actors and $48 \%$ for other actors) were national political actors. However, these figures for domestic political actors were still higher than those for EU actors.

We might expect that the new member states would focus more on domestic political actors. This tendency to be less European focused in news coverage may stem from the press in these countries being less familiar with covering EU issues and therefore placing greater reliance on domestic sources. Also, EU actors in these countries may be more difficult to identify. However, Peter et al. (2004) show that there tend to be more EU representatives in the news in countries that are holding EP elections for the first or second time than in countries that have held several elections. From the analysis of 2004 news coverage, we see little difference between old and new member states in terms of the focus placed on domestic and EU actors. In new member states, $27 \%$ of main actors and $21 \%$ of other actors in news stories were EU actors. In the old member states, the focus was similar: $25 \%$ of main actors and $21 \%$ of other actors were EU-level actors.

There were also only small differences by outlet and medium. Newspapers tend to feature greater numbers of EU and domestic political actors, whereas TV features a greater number of non-political actors. In television news stories about the election, $22 \%$ of main actors and $19 \%$ of other actors were EU political actors. In print, $26 \%$ of main actors in stories about the EU election and $21 \%$ of other actors were EU-level actors. The differences are even smaller between commercial and public service broadcasters. They tend 
to feature similar proportions of EU and domestic political actors, with $20 \%$ of actors in commercial news stories and $18 \%$ in public television news stories being EU-level actors. Given that public broadcasting has an educational mission, we expected that public television news would tend to have a greater EU focus, but this does not appear to be the case.

\section{With only some malice: More positive news in the new countries}

Turning to the tone of the news towards the EU, we find that most news about the EP elections that made specific reference to the EU was neutral. About $84 \%$ of the news mentioning the EU or its institutions did so in a neutral way without making explicit positive or negative evaluations. Looking at the $16 \%$ of the news that did contain explicit evaluative content, we created a mean score ranging from -1 (signifying consistently negative evaluations) to +1 (signifying consistently positive evaluations).

We look at the tone of the news in each of the member states individually so as to assess the average tone of the information available to citizens in each country. Figure 6 represents the average tone in each country. The most negative news was found in Greece and Portugal $(-0.20)$, the UK $(-0.18)$ and the Netherlands $(-0.17)$, and the most positive news was found in the Czech Republic (+0.02), Cyprus (+0.10) and Malta ( +0.11$)$. Figure 6, moreover, shows that 9 of the 10 countries with the most negatively slanted news were from the old EU-15. Conversely, 7 of the 10 countries with the least negative or even positive news were from the new member states.

Comparing the different media types in the old and new countries yields noteworthy differences. As Figure 7 shows, the average tone in the broadsheet press was negative in the old EU-15 $(-0.08)$ but positive $(+0.01)$ in the new countries. For the tabloids, the papers were negative in all the countries: -0.12 for the tabloids in the new countries and -0.13 for the tabloids in the old countries. Looking at public broadcasting news, we found that news was, on average, slightly positive $(+0.02)$ in the new countries but, on average, negative $(-0.05)$ in the old countries. There were no differences in tone between commercial television news in the old and the new countries, with all stations being marginally positive.

\section{Discussion}

Our study of the news media coverage of the 2004 European parliamentary elections in all 25 member countries of the European Union provides unprecedented insights into the first elections in the enlarged EU. The study includes 


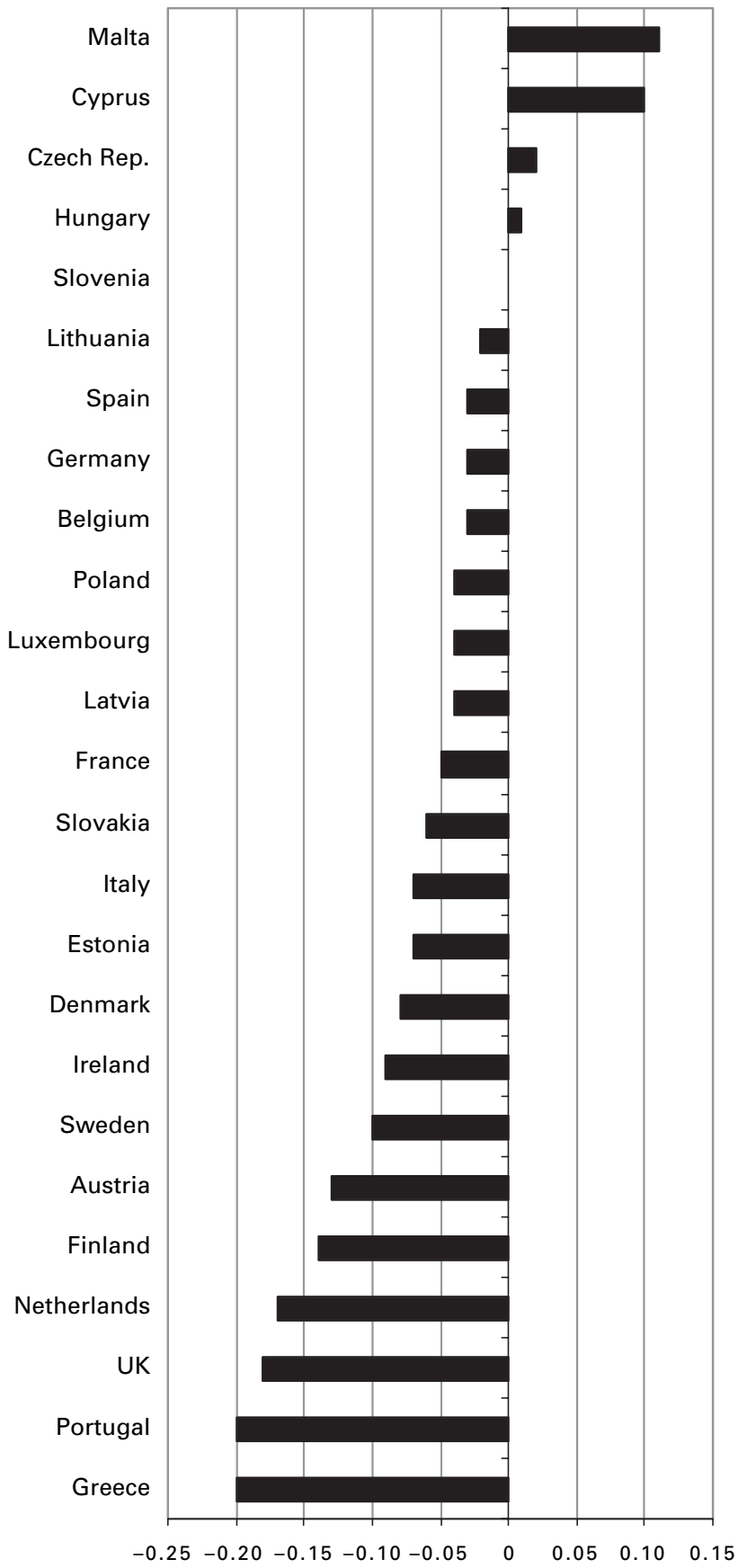

Figure 6 Tone of news (explicit evaluations EU, ranging from -1 to +1 ) by country. 


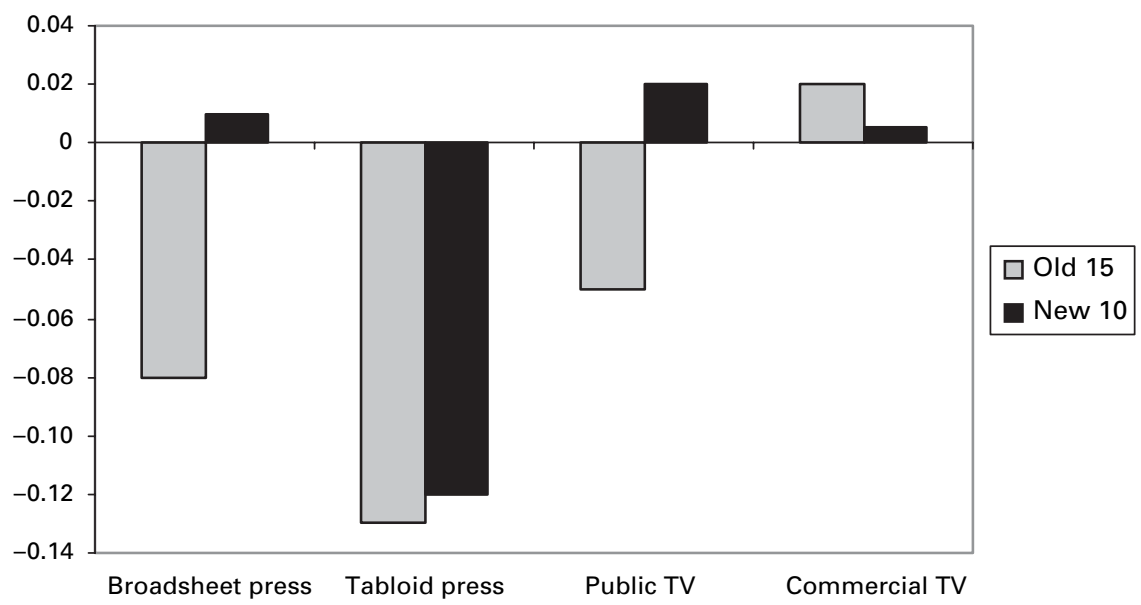

Figure 7 Tone of news (explicit evaluations EU, ranging from -1 to +1 ) by medium type.

three national newspapers and the most widely watched main evening news on commercial and public television in each country in the final two weeks leading up to the elections.

From a standpoint of democratic citizenship, a campaign has the potential to inform and mobilize voters to take part in the process of electing representatives. The media play a crucial role in this process. The EU also relies on the media indirectly to strengthen its legitimacy by increasing citizens' awareness of its activities and policies. In 1999, doubts were expressed about whether the media fulfilled this role (De Vreese et al., 2006). In some countries in 1999, the news coverage of the European elections was gloomy from the perspective of the coverage of the campaign in the most popular media outlets: the European elections were given relatively low priority in the news, they rarely made the opening of the news bulletins, and the coverage was domestic in nature, with most stories taking place in the home country and addressing issues with implications for the home country. Few representatives of EU institutions made it into the news and these EU actors were rarely quoted.

In 2004, in line with our expectations based on the increased importance of the EP and the novelty of the event in several countries, the overall visibility of the elections increased. Specifically we found that the visibility of the EP elections was higher in the 10 new EU member states than in the old member states. On television news, the elections in the old EU-15 increased in visibility compared with the previous EP election in 1999. This was not 
true for newspapers, where visibility increased in some and decreased in other old EU-15 member states. Public television news and broadsheet newspapers covered the elections more elaborately in terms of quantity of coverage than did commercial television news and tabloids in both old and new member countries.

When comparing the visibility in the old member states between 1999 and 2004 a few interesting individual country developments emerged. We found large changes in visibility in Ireland, Portugal and Denmark, although with very different patterns in these countries. Visibility in Ireland increased dramatically both on television and in newspapers. The same pattern was observed for Spanish, UK, German and Belgian news outlets, interestingly all countries in which visibility was rather low in 1999. In Portugal, by contrast, we saw visibility sharply declining, especially in newspapers but also on television news. A decrease in visibility in all news outlets was also visible in France and Italy. These countries were all in the high-mid range of visibility in 1999. Other countries show a mixed picture, with in most cases visibility going up on television and down in newspapers. In Denmark, in particular, visibility on television more than doubled, whereas it decreased more than one-third in newspapers. Finland, Sweden, the Netherlands and Greece too showed this pattern, though it was less pronounced. Among the 'new' member states, Malta stood out as the country with the highest visibility in newspapers and the second-highest on television. In Latvia, visibility was especially low in both media.

We expected differences in the visibility of EU election news between types of news outlet. Specifically, we expected higher visibility on public broadcasting news than on commercial news. Also we expected news to be more visible in the quality press than in tabloid papers. The results showed that in the old member states public broadcasting had over twice as much EU news as did commercial television news. In the new member states the general picture was the same, though the differences were less pronounced. In line with the expectations, there was more EU news in broadsheet newspapers than in tabloids. In contrast to television, the differences between the quality press and tabloid newspapers were less pronounced in the old member states and more so in the new ones. Furthermore, we expected the visibility of EU news to be higher in 2004 than in 1999, and to be higher in the new member states than in the old countries. Whereas the former was clearly the case, the pattern for the latter was less conclusive. We showed that on television, no matter whether public broadcasting or commercial news, the visibility of both EP election and other EU news was considerably higher in 2004. However, there was hardly any difference in visibility between old and new member states in public broadcasting news and the quality press. 
With respect to the domestic focus of the news, our study dovetails with previous research (e.g. De Vreese et al., 2006) in the finding that the news coverage was more domestically focused than EU focused. The actors featured in news stories about the elections were generally domestic or national political actors and not EU actors. However, there was an overall increase in the proportion of EU actors in 2004, although the coverage was still focused on domestic actors. In some countries (e.g. Malta, Portugal and France), the proportion of EU actors reached or even exceeded the proportion of domestic political actors. Moreover, countries that had a higher proportion of main protagonists that were EU actors also showed a high proportion of other actors that were from the EU. Therefore, although EP election news coverage still predominantly featured domestic political actors, there was an increase in the attention paid to EU actors. Only in the Netherlands fewer EU actors featured in the campaign coverage in 2004. Almost no change was found in Austria and Spain. Portugal sticks out, since here the visibility of EU actors increased from less than 2\% in 1999 to almost 50\% in 2004.

Our expectation that national actors would dominate the coverage of the EP election was therefore met. Looking at the results, a very consistent picture was found when comparing countries, type of medium and type of outlet. Domestic political actors dominated the news, even more so among the main actors. This pattern was basically the same for the old and the new member states. The difference in visibility between EU and domestic actors was slightly less distinctive in print news and on commercial television.

In line with expectations about the increased importance of the EP, we found that the visibility of EU actors had risen in most old member countries compared with 1999. Contrary to expectations based on previous research (Peter et al., 2004), we did not find a higher level of EU actors in new member states. Our findings thus add to extant knowledge because it is not a general rule that news in first-time election countries includes more EU actors, although news in countries that have experienced several EP elections seems to include fewer EU actors.

Our analysis of the tone of the news coverage corroborates extant research showing that most news is neutral. However, when the news was evaluative, in the old EU-15 it was generally negative towards the EU whereas in the 'new' countries a mixed pattern was found, with the broadsheet press and television news being, on average, positive and tabloid papers, on average, negative. These findings conformed to our expectations. However, we found noteworthy variation within this general pattern. The tabloid press was the most negative and the quality press and public television were positive in the new member states but negative in the old. Commercial television news was on average positive, though slightly more so in the new countries. 
Our study provides empirical evidence in a largely theoretical debate about the EU's legitimacy and its communication deficit. The benchmarks provided here, focusing on the visibility of elections, the representation of Europe and the evaluative nature of the coverage, are important for assessing the role played by the media. From the viewpoint of the European Parliament, there seems to be reason for a bit of optimism. In terms of visibility and share of EU actors, the trend between 1999 and 2004 was one of increase. The results for the new member states too offer a rather positive outlook. Visibility was relatively high, both of EU news and of EU actors. Furthermore, the tone towards the EU was considerably more positive in the new member states. However, if these findings mainly have to be ascribed to the novelty of the elections in the new countries, then caution with respect to the optimism is warranted.

In addition to these normative reflections, future research needs to investigate the specific effects of the campaign in European elections. It has previously been demonstrated that television in particular is capable of contributing to turnout in European elections (Schönbach and Lauf, 2002), especially among citizens with lower levels of political interest and awareness who may be 'trapped' by having to watch election news on television. Based on the 1999 European parliamentary election and on most previous campaigns, where there was little in the way of coverage of the campaign on the main evening television news, uninterested citizens had few opportunities accidentally to come across interesting news about the elections that might boost their interest and awareness (Schönbach and Lauf, 2002).

In relation to the 1999 elections, Banducci and Semetko $(2003,2004)$ found that the visibility of the EP campaign on television news influenced individuals' likelihood of voting in the EP election. Greater visibility on the TV news broadcasts that respondents reported watching increased the probability of voting. Contrary to expectations, negative coverage of the EU did not demobilize the electorate. Such questions still have to be addressed for the 2004 elections in the enlarged Europe, but with this study we can assess the coverage of the elections more accurately and in more detail than previously. 


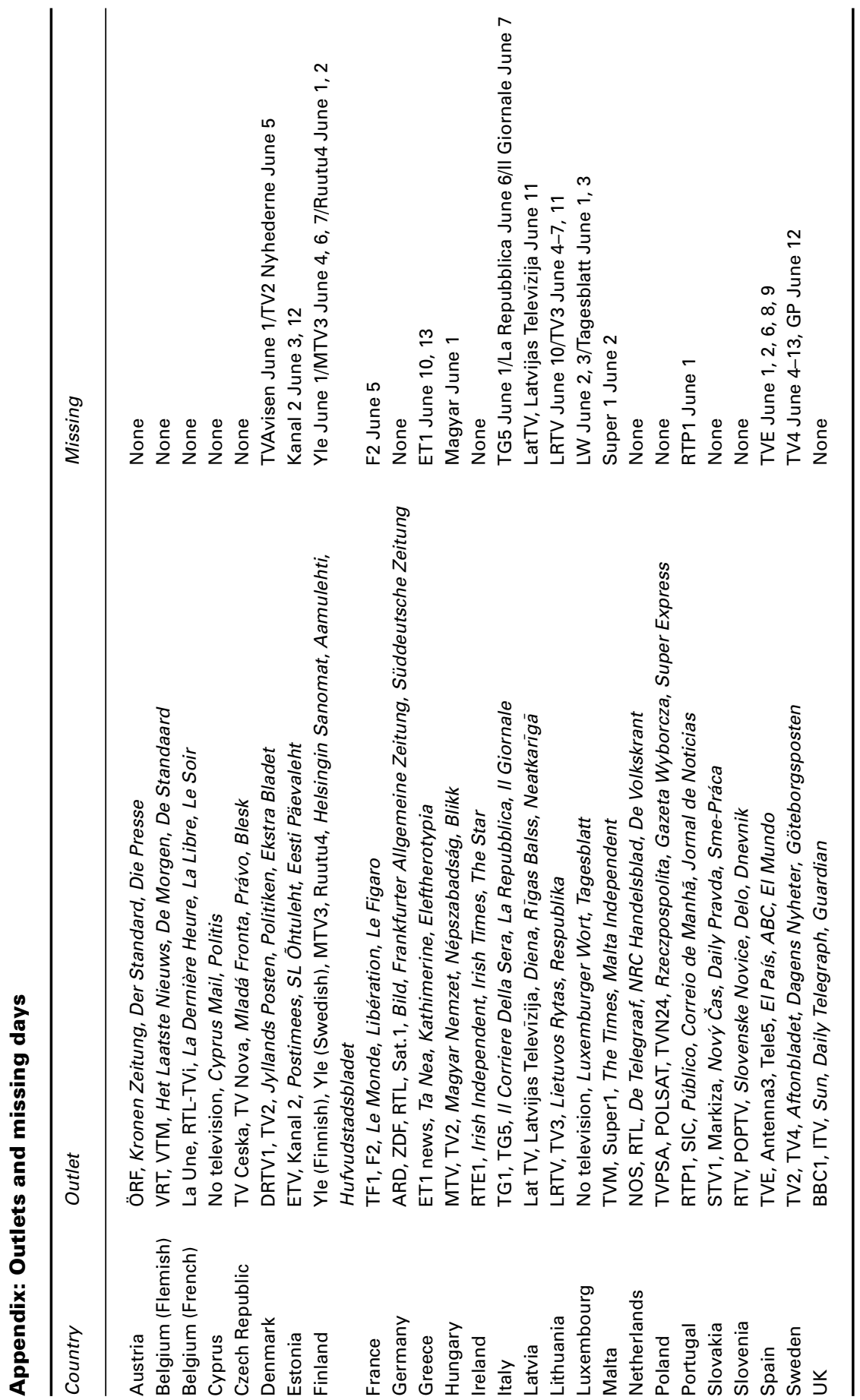




\section{Notes}

1 It should be acknowledged that the scope of the differences between public and commercial channels and their importance is contested (see Brants, 1998; Blumler, 1997).

2 The study was funded by research grants from the Dutch National Science Foundation (NWO), the Halle Foundation, the EU CIVICACTIVE Research Program, Emory University and the Amsterdam School of Communications Research / University of Amsterdam to the principal investigators - Susan Banducci, Claes H. de Vreese and Holli A. Semetko.

3 Television: in Belgium two French and two Flemish stations were included; in Finland and Germany four newscasts; in Spain and Poland three newscasts; in Austria, Greece and Ireland one newscast. We had to exclude Cyprus (for technical reasons) and Luxembourg (for linguistic reasons). Newspapers: in Belgium, three French and three Flemish newspapers were included; in Luxembourg, Malta, Lithuania and Cyprus only two newspapers were included because of availability.

4 It should be noted that a difference in coding during the 2004 study necessitated classifying actors into main protagonists (those actors that were the primary focus of the news story) and other actors (actors that were mentioned in the news story but were not the main focus).

5 The numbers that function as the base for Figure 1 (and all subsequent figures) are available in the form of a documented appendix from the authors.

6 These brief observations are based on a detailed analysis of the general news environment during the campaign period. The results of this analysis, which indicates how much attention different topics received in the news in 1999 and in 2004, are available from the authors upon request.

\section{References}

Anderson, Peter J. (2004) 'A Flag for Convenience? Discourse and Motivations of the London-based Eurosceptic Press', European Studies 20: 151-70.

Anderson, Peter J. and Aileen McLeod (2004) 'The Great Non-Communicator? The Mass Communication Deficit of the European Parliament and Its Press Directorate', Journal of Common Market Studies 42(5): 897-917.

Anderson, Peter J. and Andrew Weymouth (1999) Insulting the Public? The British Press and the European Union. London: Longman.

Banducci, Susan A. and Holli A. Semetko (2003) 'Media and Mobilization in the 1999 European Parliamentary Election', in Martyn Bond (ed.) Europe, Parliament and the Media, pp. 189-204. London: Federal Trust.

Banducci, Susan A. and Holli A. Semetko (2004) 'Media, Mobilisation and European Elections', paper presented at the workshop on Democratic Participation and Political Communication in Systems of Multi-level Governance, University College Dublin.

Banducci, Susan A., Jeffrey Karp and Edmund Lauf (2002) 'Elite Leadership, Media Coverage, and Support for European Integration', Working Paper, Amsterdam School of Communications Research. 
Bennett, W. Lance and Robert M. Entman (2001) Mediated Politics: Communication and the Future of Democracy. Cambridge: Cambridge University Press.

Blumler, Jay G. (ed.) (1983) Communicating to Voters: Television in the First European Parliamentary Elections. London: Sage.

Blumler, Jay G. (1997) 'Origins of the Crisis of Communication for Citizenship', Political Communication 14(4): 395-404.

Brants, Kees (1998) 'Who's Afraid of Infotainment?', European Journal of Communication 13(3): 315-35.

Brants, Kees and Els de Bens (2000) 'The Status of TV Broadcasting in Europe', in Jan Wieten, Graham Murdock and Peter Dahlgren (eds) Television across Europe, pp. 7-22. London: Sage.

Coultrap, John (1999) 'From Parliamentarism to Pluralism: Models of Democracy and the European Union's "Democratic Deficit"', Journal of Theoretical Politics 11: 107-35.

De Vreese, Claes H. (2002) Framing Europe: Television News and European Integration. Amsterdam: Aksant Academic Publishers.

De Vreese, Claes H. and Hajo G. Boomgaarden (2006) 'Media Effects on Public Opinion about the Enlargement of the European Union', Journal of Common Market Studies 44(2): 419-36.

De Vreese, Claes H. and Hajo G. Boomgaarden (2007) ‘News, Political Knowledge and Participation: The Differential Effects of News Media Exposure on Political Knowledge and Participation', Acta Politica (in press).

De Vreese, Claes H. and Holli A. Semetko (2004) 'News Matters: Influences on the Vote in the Danish 2000 Euro Referendum Campaign', European Journal of Political Research 43(5): 699-722.

De Vreese, Claes H., Edmund Lauf and Jochen Peter (2006) 'The Media and European Parliament Elections: Second-rate Coverage of a Second-Order Event?', in Wouter van der Brug and Cees van der Eijk (eds) European Elections and Domestic Politics: Lessons from the Past and Scenarios for the Future. Paris: University of Notre Dame Press.

De Vreese, Claes H., Jochen Peter and Holli A. Semetko (2001) 'Framing Politics at the Launch of the Euro: A Cross-National Comparative Study of Frames in the News', Political Communication 18(2): 107-22.

Eichenberg, Richard C. and Russel J. Dalton (1993) 'Europeans and the European Community: The Dynamics of Public Support for European Integration', International Organization 47: 507-34.

Gerhards, Jürgen (2000) 'Europäisierung von Ökonomie und Politik und die Trägheit der Entstehung einer europäischen Öffentlichkeit', in Maurizio Bach (ed.) Die Europäisierung nationaler Gesellschaften. Sonderheft 40 der Kölner Zeitschrift für Soziologie und Sozialpsychologie, pp. 277-305. Wiesbaden: Westdeutscher Verlag.

Grimm, Dieter (1995) Braucht Europa eine Verfassung? Munich: Carl Friedrich von Siemens Stiftung.

Grimm, Dieter (2004) 'Treaty or Constitution? The Legal Basis of the European Union after Maastricht', in Erik O. Eriksen, John E. Fossum and Augustin J. Menéndez (eds) Developing a Constitution for Europe. London: Routledge.

Hix, Simon, Tapio Raunio and M. Scully (2003) 'Fifty Years on: Research on the European Parliament', Journal of Common Market Studies 41(2): 191-202. 
Kepplinger, Hans M. and Helga Weissbecker (1991) ‘Negativität als Nachrichtenideologie', Publizistik 36(3): 330-42.

Kevin, Deirdre (2003) Europe in the Media: A Comparison of Reporting, Representation and Rhetoric in National Media Systems in Europe. London and Mahwah, NJ: Lawrence Erlbaum.

Koopmans, Ruud and Barbara Pfetsch (2003) 'Towards a Europeanised Public Sphere? Comparing Political Actors and the Media in Germany', paper presented at the international conference on Europeanisation of Public Spheres? Political Mobilisation, Public Communication, and the European Union, 20-22 June 2003, Berlin.

Kreppel, Amie (2002) The European Parliament and the Supranational Party System: A Study of Institutional Development. Cambridge: Cambridge University Press.

Kuper, Richard (1998) 'The Many Democratic Deficits of the European Union', in Albert Weale and Michael Nentwich (eds) Political Theory and the European Union, pp. 144-57. London: Routledge.

Lauf, Edmund (2001) 'The Vanishing Young Reader: Sociodemographic Determinants of Newspaper Use as a Source of Political Information in Europe, 1980-98', European Journal of Communication 16: 233-43.

Meyer, Christoph O. (1999) 'Political Legitimacy and the Invisibility of Politics: Exploring the European Union's Communication Deficit', Journal of Common Market Studies 37(4): 617-39.

Meyer, Christoph O. (2005) 'The Europeanization of Media Discourse: A Study of Quality Press Coverage of Economic Policy Co-ordination since Amsterdam', Journal of Common Market Studies 43(1): 121-48.

Norris, Pippa (2000a) 'Blaming the Messenger? Political Communications and Turnout in EU Elections', in Citizen Participation in European Politics, Demokratiutredningens skrift No. 32. Stockholm: Statens Offentliga Utredningar.

Norris, Pippa (2000b) A Virtuous Circle: Political Communications in Postindustrial Societies. Cambridge: Cambridge University Press.

Peter, Jochen and Claes H. de Vreese (2004) 'In Search of Europe - A CrossNational Comparative Study of the European Union in National Television News', Harvard Journal of Press/Politics 9(4): 3-24.

Peter, Jochen and Edmund Lauf (2002) 'Reliability in Cross-National Content Studies', Journalism and Mass Communication Quarterly 79(4): 815-32.

Peter, Jochen, Edmund Lauf and Holli A. Semetko (2004) 'Television Coverage of the 1999 European Parliamentary Elections', Political Communication 21(4): 415-33.

Peter, Jochen, Holli A. Semetko and Claes de Vreese (2003) 'EU Politics on Television News: A Cross-National Comparative Study', European Union Politics 4(3): 305-28.

Peters, Bernhard, Stefanie Sifft, Andreas Wimmel, Michael Bruggemann and Katharina Kleinen-Von Konigslow (2005) 'Seven National and Transnational Public Spheres: The Case of the EU', European Review 13: 139-60.

Pfetsch, Barbara (1996) 'Convergence through Privatization? Changing Media Environments and Televised Politics in Germany', European Journal of Communication 8(3): 425-50.

Reif, Karlheinz and Hermann Schmitt (1980) 'Nine Second-Order National 
Elections: A Conceptual Framework for the Analysis of European Election Results', European Journal of Political Research 8(1): 3-44.

Risse, Thomas and Marianne Van de Steeg (2003) 'An Emerging European Public Sphere? Empirical Evidence and Theoretical Clarifications', paper presented at the international conference on Europeanisation of Public Spheres? Political Mobilisation, Public Communication, and the European Union, 20-22 June 2003, Berlin.

Scharpf, Fritz (1999) Governing in Europe: Effective and Democratic. New York: Oxford University Press.

Schlesinger, Philip (1995) 'Europeanisation and the Media: National Identity and the Public Sphere', Arena working paper, University of Oslo.

Schlesinger, Philip (1999) 'Changing Spaces of Political Communication: The Case of the European Union', Political Communication 16(3): 263-79.

Schönbach, Klaus and Edmund Lauf (2002) "The "Trap" Effect of Television and Its Competitors', Communication Research 29: 564-83.

Semetko, Holli A. and Klaus Schönbach (1994) Germany's "Unity Election": Voters and the Media. Cresskill, NJ: Hampton Press.

Semetko, Holli A. and Patti M. Valkenburg (2000) 'Framing European Politics: A Content Analysis of Press and Television News', Journal of Communication 50(2): 93-109.

Semetko, Holli A., Jay G. Blumler, Michael Gurevitch and David H. Weaver (1991) The Formation of Campaign Agendas: A Comparative Analysis of Party and Media Roles in Recent American and British Elections. Hillsdale, NJ: Lawrence Erlbaum.

Siune, Karen (1983) 'The Campaign on Television: What Was Said and Who Said It?', in Jay Blumler (ed.) Communicating to Voters: Television in the First European Parliamentary Elections, pp. 223-40. London: Sage.

Trenz, Hans-Joerg (2004) 'Media Coverage of European Governance: Exploring the European Public Sphere in National Quality Newspapers', European Journal of Communication 19(3): 291-319.

Trenz, Hans-Joerg and Christoph Münzing (2003) "“Quo Vadis Europe?” Quality Newspapers Struggling for European Unity', paper presented at the international conference on Europeanisation of Public Spheres? Political Mobilisation, Public Communication and the European Union, 20-22 June 2003, Berlin.

Van de Steeg, Marianne (2002) 'Rethinking the Conditions for a Public Sphere in the European Union', European Journal of Social Theory 5(4): 499-519.

Van Praag, Philip and Kees Brants (eds) (2000) Tussen beeld en inhoud. Politiek en media in de verkiezingscampagne van 1998. Amsterdam: Het Spinhuis.

\section{About the authors}

Claes H. de Vreese is Professor of Political Communication and Director of the Amsterdam School of Communications Research $(A S C o R)$ at the University of Amsterdam, Kloveniersburgwal 48, 1012 CX Amsterdam, The Netherlands.

Fax: +31205253681

E-mail: C.H.deVreese@uva.nl 
Susan A. Banducci is Director at the Centre for European Studies, Politics Department, University of Exeter, Amory Building, Rennes Drive, Exeter, EX4 4RJ, UK.

Fax: +44 1392263165

E-mail: S.A.Banducci@exeter.ac.uk

Holli A. Semetko is Vice-Provost for International Affairs, Director of the Halle Institute for Global Learning and Professor of Political Science at Emory University, Box 52, Administration Bldg, Atlanta, Georgia 30322, USA.

Fax: +14047272772

E-mail: holli.semetko@emory.edu

Hajo G. Boomgaarden is a PhD candidate in the Amsterdam School of Communications Research ( $A S C o R)$ at the University of Amsterdam, Kloveniersburgwal 48, 1012 CX Amsterdam, The Netherlands.

Fax: +31205253681

E-mail: H.Boomgaarden@uva.nl 